\title{
KAJIAN TINGKAT DEKOMPOSISI SERASAH DAUN DENGAN MEMANFAATKAN AGEN PENGENDALI HAYATI TERHADAP PERTUMBUHAN DAN HASIL CABAI MERAH
}

\section{THE STUDY OF LEAF LITTER DECOMPOSITION USING BIODIVERSAL CONTROL AGENTS ON THE GROWTH AND YIELDS OF RED CHILI}

\author{
Padmini O.S. ${ }^{\star}$, R.R. Rukmowati Brotodjojo, D. Arbiwati \\ Universitas Pembangunan Nasional Veteran Yogyakarta, Yogyakarta, Indonesia \\ *Corresponding author: oktaviassarhesti@upnyk.ac.id
}

\begin{abstract}
ABSTRAK
Penurunan hasil buah cabai terutama disebabkan oleh penurunan produktivitas tanah yang disebabkan oleh penggunaan pupuk kimia yang meninggalkan pengendapan residu. Upaya peningkatan hasil cabai merah adalah selain menggunakan bahan organik, juga menggunakan agen hayati Trichoderma sp., Mikoriza sp. dan Plant Growth Promoting Regulator (PGPR). Tujuan penelitian yaitu untuk mengkaji tingkat dekomposisi serasah daun dan agen pengendali hayati+NPK terhadap pertumbuhan hasil cabai merah. Percobaan pot dilakukan di Kampus Condongcatur, Depok, Sleman, Yogyakarta mulai bulan Juni sampai November 2020. Percobaan menggunakan split plot, disusun menurut Rancangan Acak Kelompok Lengkap dengan tiga ulangan. Main plot adalah tingkat dekomposisi serasah daun dengan rasio $\mathrm{C} / \mathrm{N} 28,52$ dan rasio $\mathrm{C} / \mathrm{N}$ 16,57. Sub plot adalah jenis agen pengendali hayati dengan enam perlakuan sebagai berikut: 1) Hanya menggunakan NPK dosis rekomendasi $\left(500 \mathrm{~kg}^{-h^{-1}}\right)$, 2) Kombinasi Trichoderma $+50 \%$ dosis NPK, 3), Kombinasi Mikoriza sp. + $50 \%$ dosis NPK, 4) Kombinasi PGPR + $50 \%$ dosis NPK, 5) Lem pengendalian hama, 6) Stimulan. Data dianalisis varians, bila berpengaruh nyata dilanjutkan denga Uji Jarak Berganda Duncan taraf $5 \%$. Hasil penelitian menunjukkan bahwa dekomposisi serasah daun dengan rasio $\mathrm{C} / \mathrm{N}$ 16,57 meningkatkan tinggi tanaman umur 3 MST, jumlah cabang umur 5 dan 7 MST, serta jumlah buah dan bobot buah panen pertama dan kedua dibandingkan dengan perlakuan dekomposisi serasah daun dengan rasio $\mathrm{C} / \mathrm{N} 28,52$. Tanaman lebih tinggi pada penyemprotan stimulan $+50 \%$ dosis NPK, tetapi tidak diikuti oleh pertumbuhan cabang, serta jumlah dan bobot buah. Kombinasi agen pengendali hayati jenis Trichoderma sp, Mikoriza sp. dan PGPR + dosis 50\% NPK meningkatkan jumlah cabang serta menghasilkan jumlah dan bobot buah, namun, tidak ada perbedaan yang signifikan antara ketiga jenis agen pengendali hayati. Pertumbuhan tanaman yang hanya diberi pupuk NPK tanamannya paling rendah dibandingkan dengan perlakuan lainnya.
\end{abstract}

Kata kunci: Dekomposisi serasah daun, agen hayati, cabai

\begin{abstract}
The decline in chili fruit yield was mainly due to a decrease in soil productivity caused by the use of chemical fertilizers which left residual deposition. Efforts to increase the yield of red chilies are not only using organic materials but also using biological agents Trichoderma sp., Mycorrhiza sp. and Plant Growth Promoting Regulator (PGPR). The
\end{abstract}


research objective was to assess the decomposition rate of leaf litter and biological control agents + NPK on the yield growth of red chilies. The pot experiment was carried out at the Condongcatur Campus, Depok, Sleman, Yogyakarta from June to November 2020. The experiment used a split plot, arranged according to a Complete Randomized Block Design with three replications. The main plot was the level of leaf litter decomposition with a $\mathrm{C} / \mathrm{N}$ ratio of 28.52 and a $\mathrm{C} / \mathrm{N}$ ratio of 16.57 . The sub-plot is a type of biological control agent with six treatments as follows: 1) Only using the recommended dose of NPK (500 kg.ha-1), 2) Trichoderma combination + 50\% NPK dose, 3) Mycorrhiza sp. combination $+50 \%$ NPK dose, 4 ) Combination of PGPR $+50 \%$ NPK dose, 5) Pest control glue, 6) Stimulant. Data were analyzed for variance, if the significant effect was continued, Duncan's Multiple Range Test at $5 \%$ level. The results showed that the decomposition of leaf litter with a $\mathrm{C} / \mathrm{N}$ ratio of 16.57 increased plant height at 3 WAP, number of branches aged 5 and 7 WAP, as well as the number of fruit and fruit weight of the first and second harvest compared to leaf litter decomposition treatment with a $\mathrm{C} /$ ratio N 28.52. Plants were higher in stimulant spraying $+50 \%$ of the NPK dose, but not followed by branch growth, as well as the number and weight of fruit. Combination of biological control agents of Trichoderma sp, Mycorrhiza sp. and PGPR $+50 \%$ NPK dose increased the number of branches and yielded fruit number and weight, however, there was no significant difference between the three types of biological control agents. Plant growth that was only given the lowest NPK fertilizer compared to other treatments.

Key words: Leaf litter decomposition, biological control agents, and chili

\section{PENDAHULUAN}

Cabai (Capsicum annuum L.) merupakan komoditas hortikultura yang memiliki nilai ekonomis tinggi. Cabai dikonsumsi dalam bentuk segar atau olahan atau sebagai bahan baku industri untuk obat-obatan, pewarna, dan kegunaan lainnya (Fitria, 2019). Keistimewaan cabai yaitu memiliki kandungan vitamin A, C dan B1 pada setiap $100 \mathrm{~g}$ adalah Vitamin A (470 SI), Vitamin C (18 mg) dan Vitamin B1 $(0.1 \mathrm{mg})$. Perkembangan produktivitas (kuintal/ha) cabai Indonesia periode 2011 - 2016 menunjukkan pergerakannya melambat, bahkan menurun pada tahun 2016, produktivitas cabai besar dari tahun 2012-2016 masing-masing sebesar 79,34 ku/ha, 81,61 ku / ha, 83,35 ku/ha, 86,49 ku/ha dan 84,73 ku / ha (BPS, 2019; Fajar 2018). Masalah utama gagal panen cabai adalah penyakit keriting (bulai) yang disebabkan oleh virus Gemini dan layu Fusarium yang disebabkan oleh jamur Fusarium. Penurunan hasil dan kualitas buah cabai juga disebabkan oleh serangan lalat buah dan thrips sebagai vektor pembawa virus. Untuk mengendalikan hama tersebut, petani masih mengandalkan penggunaan pestisida kimiawi sintetis yang meninggalkan residu pada produk dan lingkungan serta mengganggu kesehatan manusia serta tanaman menjadi tahan terhadap serangan patogen. Upaya peningkatan produktivitas cabai membutuhkan terobosan teknologi.

Terobosan teknologi baru diutamakan pada penggunaan teknologi pemupukan yang lengkap dan berimbang, penggunaan pupuk organik terstandar dan dolomit sebagai unsur penting dcalam meningkatkan kesuburan tanah, serta teknologi pengendalian hama dan penyakit terintegrasi. Hama utama yang menyerang tanaman cabai adalah patogen tular tanah, virus Gemini, layu 
Fusarium, serta Thrips dan lalat buah. Upaya untuk mengatasi masalah dan mengurangi dampak negatif penggunaan pestisida sintetis dilakukan untuk pengendalian biologis. Ketersediaan agen hayati dalam jumlah yang cukup dengan kualitas yang dapat dipertanggungjawabkan sebagai agen pengendali hayati sangat penting. Upaya lain pengendalian patogen, peningkatan hasil, dan mutu cabai merah adalah dengan menggunakan kompos. Selama pengomposan terjadi perubahan fisika dan kimia dari bahan organik (Kutsanedzie et al., 2015), juga peningkatan aktivitas mikroorganisme seperti jamur, bakteri dan aktinomycetes (Omar et al., 2011). Kualitas kompos ditentukan oleh tingkat kematangannya. Keberhasilan dan kecepatan proses pembuatan kompos sangat ditentukan oleh banyak faktor, antara lain rasio $\mathrm{C} / \mathrm{N}$ bahan, ukuran partikel bahan, jumlah mikroorganisme, temperatur, kelembaban, aerasi, dan $\mathrm{pH}$ (Iskandar, 2014). Kompos yang masih segar atau baru bila diaplikasikan terhadap tanaman, maka pertumbuhan dan perkembangan tanaman akan terganggu, hal ini disebabkan karena terjadi imobilisasi atau perubahan bentuk hara $\mathrm{N}$ menjadi bentuk yang tidak tersedia bagi tanaman. Selain itu, kompos yang belum matang apabila diberikan pada tanah mengalami dekomposisi secara anaerobik sehingga menghasilkan senyawa-senyawa fitotoksik seperti ammonia, nitrit-nitrogen, besi dan mangan (Setyorini et al., 2006).

Pemberian pupuk organik dapat meningkatkan kualitas lahan karena berperan dalam memperbaiki struktur tanah, sebagai sumber hara, meningkatkan kemampuan menahan air, meningkatkan kapasitas tukar kation tanah (KTK) dan sebagai energi bagi mikroorganisme pada saat dekomposisi (Hardjowigeno, 2010). Penguraian bahan organik merupakan perubahan fisik dan kimiawi sederhana oleh mikroorganisme tanah, termasuk bakteri, cendawan, dan hewan tanah lainnya menjadi senyawa anorganik sederhana (Susanti dan Halwany, 2017). Mikroorganisme termasuk agensia hayati dalam tanah memegang peranan penting karena dapat menguraikan bahan organik dalam hal ini serasah daun segar dan melepaskan unsur hara ke dalam tanah menjadi bentuk yang tersedia bagi tumbuhan (Choirul, 2010; Iskandar, 2014). Penguraian akan berjalan lebih cepat jika terdapat tambahan mikroorganisme. Penambahan cendawan pada serasah daun diharapkan proses dekomposisi dapat lebih cepat (Aisyah dan Kuswytasari, 2014).

Penggunaan Trichoderma $s p$. merupakan alternatif dalam meningkatkan aktivitas biologi mikro organisme tanah. Trichoderma herzianum adalah jamur antagonis yang paling banyak digunakan untuk mengendalikan patogen tular tanah (agen biologis), organisme pembusuk, dan merangsang pertumbuhan tanaman. Menurut Islami et al. (2019). Pemberian Trichoderma herzianum berpengaruh baik terhadap pertumbuhan dan hasil tanaman kedelai. Penerapan Mikoriza sp. membantu meningkatkan pertumbuhan dan produksi tanaman dengan cara meningkatkan daya serap air dan unsur hara di dalam tanah, terutama fosfor. Fosfor merupakan unsur hara esensial yang dibutuhkan tanaman dalam jumlah banyak (Powell and Bagyaraj, 1984). Rhizobacteria yang mempromosikan Pertumbuhan Tanaman bermanfaat bagi pertumbuhan dan kesehatan tanah, serta memiliki kemampuan untuk mengendalikan hama dan penyakit serta dianggap penting dalam pertanian berkelanjutan (Sharma et al., 2017). Selain itu, terbukti juga mempercepat proses bioremediasi dan 
biodegradasi senyawa toksik yang terdapat pada tanah, air, logam berat, dan polutan organik (Srivastava dan Singh. 2019.

Penggunaan mikroorganisme untuk mengendalikan serangan patogen dan penggunaan pupuk organik pada tanaman cabai telah banyak diteliti. Penelitian tentang penggunaan kombinasi agen hayati diantaranya PGPR, Trichoderma sp, dan Mikoriza sp. tidak banyak yang dilakukan. Penelitian tentang pemanfaatan agen hayati dan tingkat kematangan serasah daun sangat penting dilakukan untuk menentukan memperoleh hasil dan kualitas hasil beberapa varietas tanaman cabai merah terbaik

Pengendalian hayati dengan menggunakan agen pengendalian hayati $(\mathrm{APH})$ merupakan salah satu alternatif untuk mengantisipasi dampak serangan hama. Agen pengendalian hayati ini dimanfaatkan karena dapat menekan pertumbuhan hama dalam waktu yang lebih lama, sehingga tidak meninggalkan residu dan dapat mempercepat proses penguraian bahan organik (Ningsih, 2016). Menurut Sihombing et al. (2013), pemberian Trichoderma sp. dalam budidaya bawang merah memiliki pengaruh nyata terhadap parameter tinggi tanaman dan bobot segar per plot. Hal ini disebabkan karena penambahan Trichoderma sp. menghasilkan ekskresi hormon auksin yang meningkatkan laju pertumbuhan dan efisiensi penggunaan nutrisi (Bugisinesia et al., 2008). Aplikasi Trichoderma sp. memberikan respon baik pada beberapa parameter pengamatan yaitu jumlah daun, bobot basah per tanaman, bobot basah per petak, dan bobot kering per petak (Sukmasari dan lkeu, 2018)

\section{METODE PENELITIAN}

Percobaan dalam polt di lapangan dilakukan di Kampus Condongcatur, Depok, Sleman, Yogyakarta dari bulan Juni sampai November 2020. Percobaan menggunakan split plot, disusun menurut Rancangan Acak Kelompok Lengkap dengan tiga ulangan. Sebagai Main plot adalah Dekomposisi serasah daun dengan rasio $\mathrm{C} / \mathrm{N} 28,52$ dan dekomposisi serasah daun dengan rasio $\mathrm{C} / \mathrm{N} 16,57$. Sub plot adalah jenis agen pengendali hayati dengan enam perlakuan sebagai berikut: 1) Hanya menggunakan NPK dosis rekomendasi (500 kg.ha-1), 2) Kombinasi Trichoderma + $50 \%$ dosis NPK, 3) Kombinasi Mikoriza sp. $+50 \%$ dosis NPK, 4) Kombinasi PGPR + $50 \%$ dosis NPK, 5) Lem pengendalian hama, 6) Stimulan. Data dianalisis varians dengan taraf $5 \%$. Apabila ada beda nyata antara perlakuan dilanjutkan dengan Uji Jarak Berganda Duncan taraf 5\%.

Varietas cabai yang digunakan dalam penelitian ini adalah varietas hibrida Tropy F1. Bibit ditanam dalam polibag berukuran $35 \mathrm{~cm}$ berisi tanah yang dicampur kompos sesuai perlakuan dengan perbandingan 1:1. Pupuk NPK 50\% dosis rekomendasi $(500 \mathrm{~kg} / \mathrm{ha})$, agen pengendali hayati Trichoderma sp, Mikoriza $s p$. dan PGPR, pengendali hama menggunakan lem ajaib dan stimulant, pengamatan tinggi tananan, jumlah cabang. Jumlah buah dan bobot buah.

\section{HASIL DAN PEMBAHASAN}

Penerapan dekomposisi serasah daun dengan rasio C/N 16,57 secara signifikan meningkatkan tinggi tanaman pada 3 MST dibandingkan dengan cabai yang diberi perlakuan dekomposisi serasah daun dengan rasio $C / N$ 28,52, 
namun tidak berbeda nyata di antara kedua perlakuan pada 5 MST, dan 7 MST. Penyemprotan stimulan setiap minggu tidak berbeda nyata dengan pemberian agensia hayati jenis PGPR $+50 \%$ dosis NPK. Kedua perlakuan tersebut tanamannya lebih tinggi pada umur 3, 5 dan 7 MST dibandingkan dengan pemberian agensia pengendali hayati jenis Mikoriza sp dan Tricoderma sp. $+50 \%$ dosis NPK (Tabel 1).

Dekomposisi serasah daun yang memiliki rasio C/N 10-20 meningkatkan bahan organik. Peningkatan bahan organik yang berasal dari serasah daun yang membusuk sempurna (rasio $\mathrm{C} / \mathrm{N} 16,57$ dan bahan organik $78,86 \%$ ) akan mensuplai unsur hara makro dan mikro bagi tanaman dan menciptakan kondisi tanah yang ideal untuk perkembangan semua mikroba.

Peran mikroba dalam serasah daun adalah untuk menguraikan bahan organik besar menjadi molekul yang lebih kecil. Dekomposisi, Bacillus sp. menghasilkan enzim protease; Bakteri asam laktat menguraikan gula menjadi asam laktat, asam format, etanol, dan $\mathrm{CO}_{2}$; ragi mengubah gula menjadi etil alkohol dan $\mathrm{CO}_{2}$. Ragi digunakan untuk proses fermentasi (Kosit, 2011). Agen hayati yang menguntungkan mengandung 1) mikroba utama sebagai penyedia unsur N, P, K melalui biosintetik, bio enzimatis dan fiksasi sehingga tersedia bagi tumbuhan; 2) Mikroba sekunder penghasil makanan sumber perkembangbiakan semua mikroba dalam asosiasi biotik (Ngrembakatingkir.blogspot.com. 2011). Bahan organik berpengaruh baik pada peningkatan kesuburan tanah. Ketersediaan unsur hara makro dan mikro ditandai dengan meningkatnya tinggi tanaman. Demikian pula Stimulan mengandung nutrisi, hormon auksin dan unsur hara mikro yang memperkuat pertumbuhan batang. Auksin berpengaruh pada pertumbuhan tunas (Wattimena, 2001) yang ditunjukkan dengan meningkatnya tinggi tanaman.

Penerapan dekomposisi serasah daun dengan rasio C/N 16,57 secara signifikan meningkatkan jumlah cabang pada 5 dan 7 MST dibandingkan dengan cabai yang diberi perlakuan dekomposisi serasah daun dengan rasio C/N 28,52.

Table 1. Perlakuan tingkat dekomposisi serasah daun dan jenis agensia hayati terhadap tinggi tanaman cabai umur 3, 5 dan 7 MST

\begin{tabular}{|c|c|c|c|}
\hline \multirow{2}{*}{ Perlakuan } & \multicolumn{3}{|c|}{ Tinggi tanaman $(\mathbf{c m})$} \\
\hline & 3 MST & 5 MST & 7 MST \\
\hline \multicolumn{4}{|l|}{ Laju dekomposisi seresah daun (S) } \\
\hline $\begin{array}{l}\text { Dekomposisi seresah daun dengan } \\
\text { rasio } C / N 28,52\left(S_{1}\right)\end{array}$ & $34,56 \mathrm{~b}$ & $71,89 a$ & $83,94 a$ \\
\hline $\begin{array}{l}\text { Dekomposisi seresah daun dengan } \\
\left.\text { rasio C/N 16,57 }\left(\mathrm{S}_{2}\right)\right)\end{array}$ & $36,44 \mathrm{a}$ & $77,56 \mathrm{a}$ & $87,61 \mathrm{a}$ \\
\hline \multicolumn{4}{|l|}{ Jenis agensia hayati $(A)$} \\
\hline Hanya NPK dosis rekomendasi $\left(\mathrm{A}_{0}\right)$ & $36,67 \mathrm{pq}$ & $68,83 r$ & $80,33 \mathrm{r}$ \\
\hline Kombinasi Trichoderma $+50 \%$ dosis NPK $\left(A_{1}\right)$ & $35,83 q$ & $73,50 \mathrm{q}$ & $83,00 \mathrm{r}$ \\
\hline Kombinasi Mikoriza $+50 \%$ dosis NPK $\left(\mathrm{A}_{2}\right)$ & $34,33 \mathrm{q}$ & $74,50 \mathrm{q}$ & $83,00 \mathrm{gr}$ \\
\hline Kombinasi PGPR $+50 \%$ dosis NPK $\left(\mathrm{A}_{3}\right)$ & $34,33 q$ & $76,00 \mathrm{pq}$ & $85,50 \mathrm{pqr}$ \\
\hline Lem pengendali hama $\left(A_{4}\right)$ & $34,33 \mathrm{q}$ & $82,67 \mathrm{pq}$ & $86,83 \mathrm{pq}$ \\
\hline Stimulant $\left(A_{5}\right)$ & $37,50 \mathrm{p}$ & $83,00 \mathrm{p}$ & $96,00 \mathrm{p}$ \\
\hline
\end{tabular}

Keterangan: Angka yang diikuti oleh huruf sama dalam satu kolom tidak berbeda nyata satu sama lain pada $\mathrm{P} \leq 0,05$ (DMRT). 
Table 2. Perlakuan tingkat dekomposisi serasah daun dan jenis agensia hayati terhadap jumlah cabang umur 5 dan 7 MST

\begin{tabular}{|c|c|c|}
\hline Perlakuan & 5 MST & $7 \mathrm{MST}$ \\
\hline Laju dekomposisi seresah daun (S) & & \\
\hline $\begin{array}{l}\text { Dekomposisi seresah daun dengan rasio } \mathrm{C} / \mathrm{N} 28,52 \\
\left(\mathrm{~S}_{1}\right)\end{array}$ & $19,39 b$ & $22,89 \mathrm{~b}$ \\
\hline $\begin{array}{l}\text { Dekomposisi seresah daun dengan rasio } \mathrm{C} / \mathrm{N} 16,57 \\
\left.\left(\mathrm{~S}_{2}\right)\right)\end{array}$ & $23,17 \mathrm{a}$ & $28,67 \mathrm{a}$ \\
\hline Jenis agensia hayati $(A)$ & & \\
\hline Hanya NPK dosis rekomendasi $\left(\mathrm{A}_{0}\right)$ & $20,33 p$ & $23,83 q$ \\
\hline Kombinasi Trichoderma $+50 \%$ dosis NPK $\left(A_{1}\right)$ & $21,17 \mathrm{p}$ & $26,83 p$ \\
\hline Kombinasi Mikoriza $+50 \%$ dosis NPK $\left(\mathrm{A}_{2}\right)$ & $22,67 p$ & $27,00 p$ \\
\hline Kombinasi PGPR $+50 \%$ dosis NPK $\left(A_{3}\right)$ & $22,50 \mathrm{p}$ & $27,33 p$ \\
\hline Lem pengendali hama $\left(A_{4}\right)$ & $20,82 \mathrm{p}$ & $25,00 \mathrm{pq}$ \\
\hline Stimulant $\left(A_{5}\right)$ & $20,17 \mathrm{p}$ & $24,17 \mathrm{q}$ \\
\hline
\end{tabular}

Pemberian ketiga jenis agensia hayati mempunyai jumlah cabang nyata lebih banyak dibandingkan dengan penyemprotan stimulan dan pupuk kimia NPK dosis rekomendasi $500 \mathrm{~kg} / \mathrm{ha}$ (Tabel 2). Bahan organik tinggi dengan $\mathrm{C} / \mathrm{N}$ rasio rendan, yaitu 16,57 menghasilkan pertumbuhan cabang lebih baik, karena unsur hara tersedia bagi tanaman. Menurut Suresh et al. (2011) C/N ratio antara 10-20 ditandai dengan meningkatnya aktivitas pertumbuhan mikroorganisme yang menguntungkan. Mikroorganisme tersebut dapat meningkatkan serapan dan efisiensi mikronutrien seperti $\mathrm{Zn}, \mathrm{Cu}, \mathrm{Fe}$ dan $\mathrm{Mg}$ ). Meningkatnya tinggi tanaman kerena perlakuan penyemprotan larutan stimulant (Tabel 1) tidak diikuti penambahan jumlah cabang pada Tabel 2. Jumlah cabang nyata lebih banyak pada pemberian Trichoderma sp, Mikoriza dan PGPR $+50 \%$ dosis NPK.

Agensia hayati tersebut sangat penting dalam membantu pertumbuhan cabang tanaman dengan memberikan nutrisi (misal mikroba pengikat N, mikroba pelarut P), membantu penyerapan nutrisi (misal jamur arbuskular mikoriza), merangsang pertumbuhan tanaman (misal: stimulan), dan pengendalian hama dan penyakit (misalnya mikroba penghasil antibiotik, antipathogen) (Kosit, 2011). Berbagai unsur hara makro dan mikro, fitohormon dan biopestisida yang mampu memenuhi sebagian besar unsur hara yang dibutuhkan untuk pertumbuhan dan perkembangan tanaman.

Penerapan dekomposisi serasah daun dengan rasio $\mathrm{C} / \mathrm{N}$ 16,57 secara signifikan meningkatkan jumlah buah pada panen pertama dan panen kedua dibandingkan dengan tanaman yang diberi perlakuan dekomposisi serasah daun dengan rasio $\mathrm{C} / \mathrm{N}$ 28,52. Pemberian agensia pengendali hayati jenis Trichoderma sp, Mikoriza dan PGPR+ $50 \%$ dosis NPK menghasilkan buah nyata lebih banyak pada panen pertama, kedua dan ketiga dibandingkan dengan penyemprotan stimulan an pupuk NPK saja (Tabel 3). 
Table 3. Perlakuan tingkat dekomposisi serasah daun dan jenis agensia hayati terhadap jumlah buah panen pertama, kedua dan ketiga

\begin{tabular}{|c|c|c|c|}
\hline \multirow{2}{*}{ Perlakuan } & \multicolumn{3}{|c|}{ Jumlah Buah (buah) } \\
\hline & Panen 1 & Panen 2 & Panen 3 \\
\hline \multicolumn{4}{|l|}{ Laju dekomposisi seresah daun (S) } \\
\hline $\begin{array}{l}\text { Dekomposisi seresah daun dengan rasio } \\
\mathrm{C} / \mathrm{N} 28.27\left(\mathrm{~S}_{1}\right)\end{array}$ & $6,61 \mathrm{~b}$ & $10,50 \mathrm{~b}$ & $10,22 \mathrm{a}$ \\
\hline $\begin{array}{l}\text { Dekomposisi seresah daun dengan rasio } \\
\left.\mathrm{C} / \mathrm{N} 16.57\left(\mathrm{~S}_{2}\right)\right)\end{array}$ & $9,83 a$ & $22,50 \mathrm{a}$ & $11,06 \mathrm{a}$ \\
\hline \multicolumn{4}{|l|}{ Jenis agensia hayati $(A)$} \\
\hline Hanya NPK dosis rekomendasi $\left(\mathrm{A}_{0}\right)$ & $4,50 q$ & $14,82 \mathrm{q}$ & $9,33 \mathrm{q}$ \\
\hline $\begin{array}{l}\text { Kombinasi Trichoderma }+50 \% \text { dosis NPK } \\
\left(A_{1}\right)\end{array}$ & $4,50 q$ & $17,00 \mathrm{pq}$ & $12,00 p$ \\
\hline Kombinasi Mikoriza $+50 \%$ dosis NPK $\left(\mathrm{A}_{2}\right)$ & $9,17 \mathrm{pq}$ & $16,00 \mathrm{pq}$ & $12,83 p$ \\
\hline Kombinasi PGPR + 50\% dosis NPK $\left(\mathrm{A}_{3}\right)$ & $10,17 p$ & $24,83 p$ & $12,00 p$ \\
\hline Lem pengendali hama $\left(\mathrm{A}_{4}\right)$ & $10,00 p$ & $16,50 p$ & $11,67 p$ \\
\hline Stimulant $\left(A_{5}\right)$ & $7,00 \mathrm{q}$ & $12,83 \mathrm{q}$ & $6,00 \mathrm{q}$ \\
\hline
\end{tabular}

Pertumbuhan tanaman vegetatif yang baik berkorelasi positif dengan pertumbuhan generatif. Ditunjukkan dengan meningkatnya jumlah cabang diikuti dengan meningkatnya jumlah buah. Setiap cabang tanaman cabai selalu diikuti dengan munculnya bunga. Inisiasi bunga merupakan akumulasi metabolit terutama asam amino dan asam nukleat. Senyawa organik tersebut berasal dari proses fotosintesis di setiap ujung percabangan ataupun ujung tangkai daun (Taiz dan Zeiger, 2001). Sebaliknya penggunaan stimulant tidak mendukung pertumbuhan jumlah cabang umur 7 MST yang diikuti dengan pengurangan jumlah buah pada setiap panen. Stimulat yang diperkaya dengan hormon tanaman dan formula anti kedil membuat tanaman jadi besar dan memacu proses rejuvenil, tetapi apabila tidak diikuti dengan penambahan unsur hara maka proses proses metabolisme tanaman tidak seimbang.

Penerapan dekomposisi serasah daun dengan rasio $\mathrm{C} / \mathrm{N}$ 16,57 secara signifikan meningkatkan bobot buah pada panen pertama dan panen kedua dibandingkan dengan tanaman yang diberi perlakuan dekomposisi serasah daun dengan rasio $\mathrm{C} / \mathrm{N} 28,52$, pemberian agensia pengendali hayati jenis Trichoderma $s p$, Mikoriza sp dan PGPR ditambah 50\% dosis NPK menghasilkan buah nyata lebih nyata lebih berat pada panen pertama, kedua dan ketiga dibandingkan dengan penyemprotan stimulan dan pupuk NPK saja (Tabel 4). 
Table 4. Perlakuan tingkat dekomposisi serasah daun dan jenis agensia hayati terhadap bobot buah panen bertama, kedua dan ketiga

\begin{tabular}{|c|c|c|c|}
\hline \multirow{2}{*}{ Perlakuan } & \multicolumn{3}{|c|}{ Bobot Buah (g) } \\
\hline & Panen 1 & Panen 2 & Panen 3 \\
\hline \multicolumn{4}{|l|}{ Laju dekomposisi seresah daun (S) } \\
\hline $\begin{array}{l}\text { Dekomposisi seresah daun dengan rasio } \mathrm{C} / \mathrm{N} \\
28.52\left(\mathrm{~S}_{1}\right)\end{array}$ & $17,84 \mathrm{~b}$ & $33,49 \mathrm{~b}$ & 34,67 a \\
\hline $\begin{array}{l}\text { Dekomposisi seresah daun dengan rasio } \mathrm{C} / \mathrm{N} \\
16.57 .52\left(\mathrm{~S}_{2}\right)\end{array}$ & $32,56 \mathrm{a}$ & 69,12 a & 39,65 a \\
\hline \multicolumn{4}{|l|}{ Jenis agensia hayati $(A)$} \\
\hline Hanya NPK dosis rekomendasi $\left(A_{0}\right)$ & $14,15 r$ & $42,80 \mathrm{qr}$ & $29,23 \mathrm{pq}$ \\
\hline Kombinasi Trichoderma $+50 \%$ dosis NPK $\left(A_{1}\right)$ & 18,07 qr & $57,95 \mathrm{q}$ & $40,49 p$ \\
\hline Kombinasi Mikoriza + 50\% dosis NPK $\left(\mathrm{A}_{2}\right)$ & $30,20 p$ & $51,60 \mathrm{q}$ & $45,08 p$ \\
\hline Kombinasi PGPR $+50 \%$ dosis NPK $\left(\mathrm{A}_{3}\right)$ & $34,43 p$ & $76,95 p$ & $46,57 p$ \\
\hline Lem pengendali hama $\left(A_{4}\right)$ & $33,70 p$ & $52,07 \mathrm{q}$ & $40,70 p$ \\
\hline Stimulant $\left(A_{5}\right)$ & $26,60 \mathrm{q}$ & $26,48 r$ & $20,83 q$ \\
\hline
\end{tabular}

Limbah seraasah dari pepohonan dan tanaman, seperti dedaunan dan ranting memiliki komposisi selulosa sebesar $45 \%$ dari berat kering bahan. Sedangkan hemiselulosa menempati $20-30 \%$ dan sisanya adalah lignin (Hanum et al., 2014). Tingginya bahan organik (78.86\%) yang ditandai dengan rendahnya $\mathrm{C} / \mathrm{N}$ rasio $(16,57)$ meningkatkan Kapasitas Tukar Kation $(\mathrm{KTK})$ dan sebagai sumber energi mikroorganisme (Harjowigeno, 2010). Penguraian bahan organik merupakan terjadinya perubahan fisik dan kimiawi oleh mikroorganisme tanah, termasuk bakteri, kapang, dan fauna tanah lainnya menjadi senyawa anorganik sederhana (Susanti dan Halwany, 2017). Ketersediaan hara yang meningkat diikuti dengan serapan hara yang meningkat mendorong kecukupan hara untuk pertumbuhan tanaman, yang ditunjukkan dengan peningkatan tinggi tanaman jumlah cabang, jumlah buah dan bobot buah yang signifikan.

Bahan organik akan mensuplai unsur hara makro dan mikro bagi tanaman dan menciptakan kondisi tanah yang ideal untuk perkembangan semua mikroba. Peran mikroba dalam serasah daun dapat menguraikan bahan organik berukuran besar menjadi ukuran lebih kecil. Selama penguraian Bacillus $s p$. menghasilkan enzim protease; Bakteri asam laktat menguraikan gula menjadi asam laktat, asam format, etanol, dan $\mathrm{CO}_{2}$; ragi mengubah gula menjadi etil alkohol dan $\mathrm{CO}_{2}$ (Kosit, 2011). Metabolisme yang dilakukan oleh mikroba tersebut menghasilkan unsur hara makro dan mikro. Selain itu hormon tumbuhan juga merupakan komponen penting dalam meningkatkan pertumbuhan tanaman. Nutrisi yang cukup dan hormon tanaman membantu menghasilkan cabang secara maksimal, dan sebagai indikator pembentukan bunga dan buah.

\section{KESIMPULAN}

Dekomposisi serasah daun dengan rasio $\mathrm{C} / \mathrm{N} 16,57$ secara signifikan meningkatkan tinggi tanaman pada hari ke umur 3 MST, jumlah cabang umur 5 dan 7 MST serta jumlah buah dan bobot buah panen pertama dan kedua 
dibandingkan dengan cabai yang diberi perlakuan dekomposisi serasah daun dengan $\mathrm{C} / \mathrm{N}$ rasio 28,52 .

Tanaman lebih tinggi pada penyemprotan stimulan $+50 \%$ dosis NPK, tetapi tidak diikuti oleh pertumbuhan cabang, serta jumlah dan bobot buah. Kombinasi agen pengendali hayati jenis Trichoderma sp, Mikoriza sp. dan PGPR + dosis $50 \%$ NPK meningkatkan jumlah cabang serta menghasilkan jumlah dan bobot buah, namun, tidak ada perbedaan yang signifikan antara ketiga jenis agen pengendali hayati. Pertumbuhan tanaman yang hanya diberi pupuk NPK memiliki pertumbuhan tanaman paling rendah dibandingkan dengan perlakuan lainnya.

\section{UCAPAN TERIMAKASIH}

Penulis mengucapkan terimakasih kepada Lembaga Penelitian dan Pengabdian Masyarakat Universitas Pembangunan Nasional Veteran Yogyakarta atas dukungan, kerjasama yang baik dan bantuan dana penelitian Teranan. Mulai persiapan hingga selesainya pelaksanaan penelitian dan sampai terwujudnya laporan penelitian ini telah berlansung aman dan lancar. Semoga laporan penelitian ini berguna bagi masyarakat, teristimewa bagi yang berkarya di bidang budidaya cabai.

\section{DAFTAR PUSTAKA}

Aisyah M. H., N. D. Kuswytasari. 2014. Laju Decomposisi Serasah Daun Trembesi (Samanea saman) dengan Penambahan Inokulum Kapang. Jurnal sains dan seni pomits vol. 3, no.1, Hal. 2337-3520

BPS, 2019. Statistical YearBook Of 2019. Biro Pusat Statistik. Jakarta.

Bugisinesia, T., U. Nurwaidah dan A. Gafar. 2008. Pengaruh Teknik Aplikasi Cendawan Antagonis Trichoderma spp Menekan Penyakit Layu Fusarium (Fusarium oxysporum) Tanaman Kentang (Solanum tuberosum L.). Prosiding Seminar IImiah dan Pertemuan Tahunan PEI dan PFI XX Komisariat Daerah Sulawesi Selatan

Choirul. 2010. Laju dekomposisi serasah daun beberapa jenis pohon pionir di plot permanen Hutan Penelitian dan Pendidikan Biologi (HPPB) Universitas Andalas Padang. Prosiding.

Fajar, M. 2018. Telaah Data Produksi Cabai Besar Dan Cabai Rawit. Univ. Padjadjaran. Bandung. $\quad$ https://www.researchgate.net/publication/ 324133429. Diakses 15 Apeil 2020.

Fitria, E. 2019. Pengaruh Varietas Dan Dosis Pelet Trichoderma Harzianum Terhadap Produksi Cabai (Capsium annum L.). Skripsi: Universitas Syah Kuala

Hanum, A. M. dan Nengah Dwianita K. 2014. Laju Dekomposisi Serasah Daun Trembesi (Samanea saman) dengan Penambahan Inokulum Kapang. Jurnal Sains dan Seni POMITS 3 (1) : 2337 - 3520.

Hardjowigeno S. 2010. Ilmu tanah. Pressindo, Jakarta

Iskandar B. 2014. Dinamika litterfall dan kecepatan dekomposisi serasah pada agroekosistem perkebunan di Kabupaten Dharmasraya. Program Studi Agroteknologi, Universitas Andalas. 
Islami, M., O. S. Padmini, Basuki. 2019. Respon Pertumbuhan dan Hasil Kedelai Edamame (Glycine max L. merrill) Pada Berbagai Dosis Pupuk Kotoran Sapi dan Trichoderma harzidianum L. Skripsi Fakultas Pertanian. UPN Veteran Yogyakarta.

Kosit, P. 2011. Kyusei Nature Farming and the adaptation of farmers in the Isan Region of Thailand. European Journal of Social Science 21 (3): 471-482.

Kutsanedzie, F., Ofori, V., and Diaba, K. (2015). Maturity and Safety of Compost Processed in HV and TW Composting Systems. International Journal of Science, Technology and Society, 3(4), 202-209. https://doi.org/10.11648/j.ijsts.20150304.24

Ningsih,H. U. S. Hastuti, D. Listyorini 2016. Kajian Antagonis Trichoderma sp. terhadap Fusarium solani Penyebab Penyakit Layu Pada Daun Cabai Rawit (Capsicum frutescens) secara In Vitro. Proceeding Biology Education Conference (ISSN: 2528-5742), Vol 13(1) 2016: 814-817

Omar, L., Ahmed, O. H., and Majid, N. M. A. (2011). Enhancing nutrient use efficiency of maize (Zea mays $L$.) from mixing urea with zeolite and peat soil water. International Journal of the Physical Sciences, 6(14), 3330-3335. https://doi.org/10.5897/IJPS11.091.

Powell, C.L. \& Bagrajy, Dj. 1984. Vesicular-arbuscular Micorriza. CRC Press. Inc. Boca Raton. Florida.

Sharma, I. P., S. Chandra, N. Kumar, and D. Chandra. 2017. Plant Growth Promoting Rhizobacteria: Heart of Soil and Their Role in Soil Fertility

Setyorini, D., Saraswati, R., dan Anwar, E. K. (2006). Kompos. In R. D. M. Simanungkalit, D. A. Suriadikarta, R. Saraswati, D. Setyorini, \& W. Hartatik (Eds.), Pupuk Organik Dan Pupuk Hayati (pp. 11-40). Bogor: Balai Besar Penelitian dan Pengembangan Sumberdaya Lahan Pertanian.

Sihombing, C., Hot S., dan Hismawan H. 2013. Tanggap Beberapa Varietas Bawang Merah (Allium ascalonicum L.) Terhadap Pemberian Trichoderma sp. Jurnal Online Agroteknologi 1(3) : 2337 - 6597.

Srivastava, R. \& Singh, A. 2017. Plant Growth Promoting Rhizobacteria (PGPR) for Sustainable Agriculture. Article International Journal of Agricultural Science and Research (IJASR)

Sukmasari, Miftah Dieni dan Ikeu Minawati. 2018.Efektifitas Agen Hayati Trichoderma sp Serta Pengaturan Jarak Tanam Terhadap Infeksi Penyakit, Pertumbuhan Dan Hasil Tanaman Bawang Merah Di Luar Musim. Jurnal Ilmu Pertanian Dan Peternakan Volume 6 No. 2, Desember 2018.

Suresh Kumar, R., P. Ganesh, K. Tharmaraj, R. Saranraj, 2011. Growth and Development of Blackgram (Vigna mungo) under Foliar Application Panchagavya as Organic Source Nutrient. Department of Microbiological, Faculty of Science, Annamalai

Susanti, P.D. \& Halwany, W. 2017. Litter Decomposition and Diversity of Soil Macrofauna on Industrial Plantation Forest of Nyawai (Ficus variegate. Blume). Jurnal Ilmu Kehutanan https://jurnal.ugm.ac.id/jikfkt . 212-223

Taiz, L. and Zeiger, E. 2001. Plant physiology. Oxford University Press 